\title{
A Preliminary Investigation of the Prevalence of Corporal Punishment of Children and Selected Co-occurring Behaviours in Households on New Providence, The Bahamas
}

\author{
Shane Brennen ${ }^{1}$, William J. Fielding, Marie C. Carroll, \\ Janice C. McCants Miller, Latanya Adderley, and Mary Ann Thompson \\ The College of The Bahamas
}

\begin{abstract}
The purpose of this study is to examine the link between violence in homes, focusing on corporal punishment of children as a means of discipline, and other behaviours (including sexual abuse, illegal drug use, domestic violence, hitting of pets) which may be a cause for concern. This paper reports the results of a survey of 933 people and 12 case studies. Violence, physical or domestic, occurred in $62 \%$ of survey participants' homes. The survey indicates that in respondents' homes many children were physically hurt as a means of discipline. Children were spanked in $77 \%$ of homes with children, pets were hit in $25 \%$ of homes with pets, and domestic violence was found in $23 \%$ of homes. These findings suggest that those who use violence in their homes may not understand the wider and longer-term consequences of their actions for both victims and society. Case study participants seem to view only severe physical violence as abuse. They also appear reluctant to report abuse to the authorities which can hamper the efforts to curb violence in homes. The following anecdote exemplifies this reaction:

A lady was looking at a car, she had a small girl with her (3 or 4 years old), "come here" she said, the little girl was gazing at her reflection in the shinny [sic] car wheels, "come here" said the woman again, the child was in her own world looking in marvel at the shiny silver wheels, the big lady took two steps over to the child, and wham, "come here" she hollered after hitting the kid...the child looked up, and did not cry, she said nothing and biting her lip she followed the lady....Nobody looked twice; nobody cared... (Aranha, 2009, para. 10).
\end{abstract}

\footnotetext{
${ }^{1}$ Shane Brennen, School of Social Sciences; William J Fielding, Planning Unit; Marie C Carroll, School of Social Sciences; Janice C. McCants Miller,' School of Social Sciences; Latanya Adderley, School of Education student; Mary A. Thompson, School of Education student, The College of The Bahamas, P.O. Box N-4912, Nassau, Bahamas.

J. C. McCants Miller is now retired from The College of The Bahamas.

Acknowledgments: The authors are grateful to Kevin Sherin for permission to use the HITS $\odot$ tool. The Fall 2008 College of The Bahamas classes of Psychology 245, Psychology 305 and Social Work 408 collected and entered the data into the computer as part of their course work. We are grateful to Terry Fountain from the Ministry of Health for allowing access to the data on child health in The Bahamas. The Ministry of Education and The College of The Bahamas Study, some of whose data we present here, on school children was funded by the Planning Unit of the Ministry of Education.

E-mail: (Corresponding author) wfielding@cob.edu.bs

How to cite this article in APA ( $6^{\text {th }}$ ed.) style: Brennen, S., Fielding, W. J., Carroll, M. C., McCants Miller, J. C., Adderley, L., \& Thompson, M. A. (2010). A preliminary investigation of the prevalence of corporal punishment of children and selected co-occurring behaviours in households on New Providence, The Bahamas. The International Journal of Bahamian Studies, 16, 1-18. https://doi.org/10.15362/ ijbs.v16i0.121
}

(C). Brennen et al. 2010. Journal compilation @ The International Journal of Bahamian Studies, 2010. 


\section{INTRODUCTION}

The link between various forms of violence in the home, namely child abuse, domestic violence and animal abuse, has been receiving ever greater attention by researchers such as Ascione and Arkow (1999) and Lockwood and Ascione (1998). Contributors in Ascione (2008) have continued to uncover the complex relationships between the three, and although not the topic of this paper, as the population ages, elder abuse has also emerged as an issue (e.g., Maruyama \& Ascione, 2008). The implications of violent behaviours are complex, inter-linked and the subject of continuing study, such as that by McPhedran (2009). Given that the family is a key unit within society, Krug, Dahlberg, Mercy, Zwi, and Lozano (2002) have found that violence which threatens its stability can ultimately lead to the destabilisation of society.

\section{Violence towards children}

Since 1990, there has been a marked rise in the number of reported incidences of child abuse despite the existence of many groups working to improve child welfare in The Bahamas (Brennen \& Social Work 420 Students, 2008). In 1990, there were 54 cases of physical abuse of children and 34 cases of sexual abuse (including incest) in The Bahamas; in 2008 this had risen to 177 cases of physical abuse and 159 cases of sexual abuse, including incest (Bahamas, Department of Social Services, 2008, 2009) in New Providence. It is expected that statistics such as these and a constant flow of media reports concerning child abuse underpin the growing concern of the Bahamian public regarding the abuse of children, domestic violence and the care of children (Palmer, Lowe, Hepburn, Strachan, Symonette, \& Moss, 2008). This concern has also been noted by researchers outside of the country. According to the U.S. Department of State's Bureau of Democracy, Human Rights and Labor (2009), "child abuse and neglect remained serious problems” in The Bahamas (Section 5, para. 8).

There appears to have been little research published about child abuse in The Bahamas. The literature review by Knowles (1999) drew heavily upon Caribbean and extra-regional literature due to the lack of studies from The Bahamas, stating that research on child abuse was "relatively new" (p. 3). Knowles noted that corporal punishment was common but "not all corporal punishment is abusive" (p. 116), and she considered abuse as "excessive discipline” (p. 117). Using a four point scale of abuse, she found that as the level of abuse increased from none, through bruises and minor cuts, to severe lacerations to neurological damage (p. 121) that self-esteem and academic self-esteem decreased while aggression and worry sensitivity increased. Within The Bahamian context, abuse of children can have important consequences for the child beyond the physical. Clearly, the implications of parents being violent towards their children are important to society and the development of the country due to its longterm effects on the child (U.S. Department of Health and Human Services, Children's Bureau, 2008).

A study of children in Bahamian schools indicated the possible extent of violence and worry in their lives. The results in Table 1 refer to a study of 1,008 students in Grades 7, 9 and 11 with a mean age of 13.9 years, $S E=0.06$. with a range from 11 to 19 years included in a Bahamian Ministry of Health survey conducted in 1999 (2001). Over $20 \%$ of students claimed to have been physically abused, and that an adult in the home was responsible in the majority of these cases; students also claimed that they were physically abused in schools by teachers. Regionally, Halcón, Blum, Beuhring, Pate, Campbell-Forrester, and Venema, (2003) found about $16 \%$ of school children reported being physically abused, so children in The Bahamas may be at higher risk of harm than elsewhere in the Caribbean. Allegations in the Bahamian press reinforce these claims of physical abuse (Thompson, 2009). Turnquest (2009) noted that violence at school occurs both inside and outside the classroom, can be severe, and may involve knives.

About $13 \%$ of school children in The Bahamas claimed to have been sexually abused and adults in the home were identified as being responsible by over $20 \%$ of the abused children. There have also been allegations of sexual abuse involving teachers (Maycock, 2009). Electronic mail comments by readers of Maycock's article indicate that violence in the classroom is not new and also that there is a divergence of opinion as to the acceptability of use of violence to discipline children. 
Table 1

Prevalence of worry and abuse among school children in The Bahamas

\begin{tabular}{lcr}
\hline $\begin{array}{l}\text { Item } \\
\text { Worries }\end{array}$ & Yes & $\begin{array}{r}\text { Number of } \\
\text { responses }\end{array}$ \\
\hline $\begin{array}{l}\text { Worry a lot about violence at } \\
\text { school }\end{array}$ & $22.6 \%$ & 913 \\
$\begin{array}{l}\text { Worry a lot about parents } \\
\text { drinking/drug use }\end{array}$ & $11.9 \%$ & 890 \\
$\begin{array}{l}\text { Worry a lot about being } \\
\text { sexually abused }\end{array}$ & $11.3 \%$ & 870 \\
$\begin{array}{l}\text { Worry a lot about being } \\
\text { physically abused }\end{array}$ & $11.2 \%$ & 875 \\
$\begin{array}{l}\text { Worry a lot about violence in } \\
\text { the home }\end{array}$ & $10.9 \%$ & 873
\end{tabular}

Abuse

Ever physically abused

$22.2 \%$

862

Ever been sexually abused

$12.9 \%$

894

Of those children who had been abused

Physically abused by an adult $\quad 71.3 \%$

178

in the household

Sexually abused by an adult

in the household

$24.8 \%$

101

Physically abused by a

$17.9 \%$

168

teacher

Treated for physical abuse

$17.7 \%$

153

Physically abused by an adult

in the home and by a teacher $\quad 10.2 \%$

166

at school

Note: Adapted from [Bahamas youth health survey] by Bahamas Ministry of Health, Health Information Unit, 2001, Unpublished raw data.

Further, Jones (2008) reported that Bahamian school "officials have identified victims of emotional abuse, sexual harassment and bullying" (para. 6) even in "little children" (para. 7). Consequently, it can be appreciated that an important proportion of children may be abused by their elders and peers, both physically and sexually. Violence, at home and at school, as well as the behaviour of parents was a source of worry to about $10 \%$ of students who answered both questions (Bahamas, Ministry of Health, Health Information Unit, 2001). As suggested by Thompson and Gullone (2003), these behaviours of their peers, physically and emotionally may provide opportunities for undesirable behaviours to be learnt. Further, the use of violence on children can have important social consequences. In Jamaica, Smith and Mosby (2003) claimed "that the harsh physical punishment meted out to children is partially responsible for the current social problems of the island nation” (p. 369), and this may also be the case in The Bahamas.

Otterbein and Otterbein (1973) suggested that the use of violence to discipline children is common when a community subscribes to supernatural beliefs as demonstrated by their study in Andros, The Bahamas. If this is correct, the fact that the majority of the population of The Bahamas professes a religious affiliation (Bahamas Department of Statistics, 2002) could result in actions motivated by the Christian Biblical reference, "spare the rod and spoil the child" (Ballance, 2008, p. 51). In fact, this saying is regarded as a Bahamian proverb (Tertullien, 2002) which may indicate the deep-seated nature of this method of rearing children. The fact that the debate about the use of violence to discipline children has appeared in the religious pages of the media (e.g., "Is sparing the rod spoiling the child?”, 2008) further suggests that it has a basis in supernatural belief. Firmin and Castle (2008) report that within a Christian context, while spanking may be appropriate when combined with "love, mercy, kindness and wisdom” (p. 123), abuse must be avoided. If parents do not recognise their actions as abusive (as they may have been abused themselves), then they may unwittingly treat their children in the same way as they were treated. Covell, Grusec and King (1995) have already noted that intergenerational transmission of discipline occurs and that disciplinary measures may be learnt within the home. Given that the use of violence to discipline children occurs throughout the Caribbean, factors other than supernatural beliefs may also be 
responsible for the use of violence in disciplining children (D’Avanzo, 2008).

The Bahamas has laws to protect children which are used to prosecute an abuser who:

wilfully assaults, ill-treats, neglects, abandons or exposes him [the child], or causes or permits him to be assaulted, illtreated, neglected, abandoned or exposed, in a manner likely to cause him unnecessary suffering or injury to health including injury to or loss of sight, or hearing, or limb, or organ of the body, and any mental derangement. (Children and Young Persons Act, 1947, [CH. 97], para. 17, 1)

It should be noted that in a trial of a 54 year-old woman who had spanked a six-month old baby, the judge was concerned about the level of violence and if the spanking had crossed the line to abuse (McKenzie, 2008). This would suggest that the law, or the judge, was not clear on what violent actions constituted abuse. This contrasts with other countries where spanking is outlawed, for example in Costa Rica ("Spanking of children outlawed", 2005), based on the recognition that spanking puts children at greater risk of abuse (Zolotor, Theodore, Chang, Berkoff, \& Runyan, 2008).

The Bahamas Department of Social Services describes child abuse as "neglect, physical injury, sexual abuse or emotional abuse inflicted or knowingly not prevented, which causes significant harm or death" (2005a, para. 1). It describes physical abuse as including "physical hurts or injuries by hitting, shaking, squeezing, burning, biting or attempting to drown or suffocate them" (2005a, para. 4). The Department of Social Service's answers to frequently asked questions on child abuse considers abuse to be mistreatment but the elaboration on the difference between discipline and abuse does not appear to be particularly helpful. The following is an example:

Physical abuse occurs when dangerous objects like, wires, brooms, and chairs, etc. are used. Physical abuse also takes place when children are hit on certain parts of their bodies like their heads, which can cause potential permanent damage. Moreover, we know that abuse is possible when anger outweighs the love in the situation at hand. Remember that discipline is not about causing pain to the child, but discipline is achieved when the child develops the innate desire to do the things that are beneficial to him/her. Therefore, while a spanking every now and again may be beneficial to a child, there are other ways in which to punish and guide the child to make the right decisions. (Bahamas, Department of Social Services, 2005b, FAQ 6)

This explanation seems to obfuscate rather than elucidate matters and does not appear entirely consistent with the law. Is hitting only abuse when it occurs with a dangerous object (but would many people consider a chair to be a dangerous object?) or if the child is hit on the head or some other delicate area? These statements give a different impression of abuse compared to the first where hitting, even with the hand, could appear to be sufficient to be considered abuse. This lack of clarity does little to guide the public as to what is and is not abuse. Consequently, although the Department of Social Services would like cases of abuse reported (2005a, para. 7) this confusion may deter such actions.

The Bahamas Crisis Centre considers physical abuse as "the intentional physical injury or pattern of injuries caused by a parent, guardian or caregiver” (n.d., para. 1). This then allows for the use of violence against children provided the child is not physically injured. As such, this definition may be less strict than the definition of physical hurts provided by the Bahamian government or by Wilson (2005) who defined physical abuse as the use of size, strength or presence to hurt or control someone else. In the United States, where definitions of physical abuse have been attempted, these have resulted in physical abuse being defined as:

Non-accidental physical assault with or without an implement: weapon, foreign object, or foreign substance (such as hitting with a stick, strap, or other hard object, as 
well as scalding, burning, poisoning, suffocating, and drowning). Category also includes slapping, spanking with hand, hitting with fist, biting, kicking, shoving, shaking, throwing, Non-accidental dropping, stabbing, choking, and physical assaults of these types using unknown means (e.g., unknown whether beating was done with hand or with implement). Category also includes permitting of physical assault, as described. Also includes "semi-accidental" injuries foreseeably resulting from physical assault (e.g., child injured from fall caused by slap or shove, infant injured when deliberately dropped or thrown). (Sedlak, 2001, p. 38).

Such a definition suggests a lower threshold of tolerance toward actions which could trigger the classification abuse than in The Bahamas. As a result, the interpretation of abuse in The Bahamas may not fit easily into the concept of abuse as interpreted elsewhere. Consequently, care must be taken when trying to understand what abuse conveys in the Bahamian context. Therefore, it would be useful to describe the perception of residents regarding actions which constitute abuse in the Bahamian context.

\section{Domestic violence}

Domestic violence in The Bahamas has attracted attention in recent years as it has gone beyond minor disputes between family members and become a leading cause of homicides. A domestic dispute may even have been responsible for the burning down of the Straw Market in Nassau (Plumridge \& Fielding, 2009, p. 1). A report from the United Nations Office on Drugs and Crime and the World Bank's Latin American and Caribbean Regional Office (2007) has indicated that domestic violence in The Bahamas is responsible for a higher rate of homicides than that seen elsewhere in the Caribbean, causing comment in the local press (e.g., Lightbourne, 2008). Burnett-Garraway (2001) found that the percentage of women at the Accident and Emergency Department of Nassau's Princess Margaret Hospital (30\%) was similar to that in other countries (p. ii) and that $40.3 \%$ had been physically abused at some time in their lives. In a recent review of the literature, McEwen (2010) talks of the "high levels of violence reported in Bahamian homes" (p. 12). In addition there are less obvious or immediate effects given the "psychological evidence that children are affected by witnessing domestic violence” (Rivett \& Kelly, 2006, p. 225). There is cause for concern for children surrounded by, or victims of, violence. Therefore, it would appear that the homes of many children may not be ideal places for them to live in.

\section{Purpose of the study}

This study was undertaken as a result of national anxiety about violence in society. The purpose of this study was to examine the extent of physical violence in homes. In particular, it looked at the link between the use of corporal punishment of children and other behaviours within the home which may be a cause for concern.

This study is a starting to point to answer questions such as:

\section{What is violence?}

2. In the view of Bahamians, when do they use corporal punishment to discipline children and when does physical punishment become abuse?

3. In what percentage of homes are children spanked as a means of discipline?

4. In what percentage of homes are children hit frequently as a means of discipline?

5. In what percentage of homes are children hit to the extent that it becomes abuse?

6. Are these behaviours linked with other behaviours in the home which may be a cause for concern?

\section{METHOD}

\section{Case studies}

Findings from 12 case studies are reported. They provide insight into the views of Bahamians regarding what is considered abuse in relation to acts of physical violence. Perceptions of physical violence and abuse are important when interpreting the data from the survey for the reasons given in the Introduction; namely there appears to be little known about the Bahamian context in relation to distinctions between 
physical violence and abuse. We interviewed members of the public chosen to get a range of ages equally divided between males and females. The case studies took the form of semi-structured interviews.

\section{The questionnaire}

The questionnaire was based on Fielding and Plumridge's (2010) and included questions relating to children in the home. The main features of the survey are summarised in Table 2. Questions on substance abuse and the presence of persons with a criminal record living in a household were included, as Bhatt (1998) linked substance abuse to domestic violence and Fukurode (2005) has found that prior convictions can increase the risk of domestic violence in the home. The survey asked questions concerning sexual abuse, attitudes towards the household and if the perpetrator of violence was the same person who harmed pets. The HITS $\odot$ tool developed by Sherin, Sinacore, Li, Zitter and Shakil (1998) was used to determine whether domestic violence was present in the respondent's household. The HITS $@$ tool asks four questions relating to hitting, intsulting, threatening and swearing, and therefore includes features of domestic violence listed by the Bahamas Crisis Centre (n.d.). Where children were part of the household, participants were asked about the use of violence to discipline children, the frequency of its use, and if the violence was perceived as abuse.

\section{Table 2}

Summary of the questions included in the survey.

Demographics of the respondent

Type of household, parent's home, own home etc.

Pets kept and their treatment

Children in the home and their treatment as it relates to

physical violence, spanking to the extent of abuse; who is

violent towards the children?

HITSC screening for domestic violence

Participation of household members in deviant behaviours

Respondent's perception of home as loving and as a place to remain
Animal abuse has been linked with child abuse and domestic violence. McPhedran (2009) has written of the relationship between animal abuse, family violence and resultant childhood "behavioral problems that may extend into adulthood” (p. 1). Fielding and Plumridge (2010) have noted that the link between animal abuse and domestic violence and selected deviant behaviours also exists in The Bahamas. Consequently, we included questions on the treatment of pets in order to determine any link with the physical abuse of children, a link reported in Ascione and Arkow, 1999, among others.

\section{Data collection}

Undergraduate students from The College of The Bahamas were trained as research assistants prior to collecting the data. The intended target population was college students aged 18 or over. This population was chosen so the results could be triangulated (on those variables such as presence of domestic violence in the home, alcohol and illegal drug use etc,) in common with Plumridge and Fielding (2009). However, due to the large number of part-time students who participated in the data collection it was found necessary to allow other persons 18 or over to participate; otherwise these students would have been unable to complete their allotted number of 25 forms. Each respondent was assumed to represent a different household. When respondents may have been a member of more than one household they were asked to give answers which related only to their present household. The selection of participants represented a convenience sample. For simplicity of interpretation of the results, only respondents who lived in their own homes or with other relatives were included in the analysis. Those in non-family settings such as dormitories were excluded from the analysis.

All participants signed a consent form which stated the voluntary nature of the study and its aims. Confidentiality of the data was stressed to all participants, both orally and in writing, and the study was undertaken with the consent of the College of The Bahamas' Office of Research, International Relations and Graduate Programmes. 


\section{RESULTS}

\section{Case studies}

The cases included five males (aged between 23 and 45 years old) and seven females (aged between 18 and 57). Five respondents were single, two in common-law marriages, three married and two divorced; between them they cared for 27 children.

\section{Perceptions of violence}

Respondents' views of what they perceived violence to be included:

- "hurting someone physically"

- “any form of bodily harm”

- "causing bodily harm"

- "violence is any acts [sic] done with intentions of causing harm to another human being or animal”

- "cause harm to someone out of anger"

- "killing and stabbing another person"

Respondents gave examples of violent acts which included, "fighting, robbing etc.", "any physical acts [sic] which is done out of anger", "beating someone up, or shooting someone", "shooting, stabbing or beating up someone", "getting viciously attack [sic]" and "beating someone up". Physical punishment was considered to be a violent act when:

- "you beat up on someone and scars or bruises are left on the person"

- "the punishment does not fit the crime"

- "there is bodily harm like swelling, bruises or is blood is shed"

- "someone gets hurt, blood is shed"

- "there is physical harm for example if you stab someone or brutalise someone"

- "a person is harmed in any way"

Two respondents thought that hitting someone was a violent act, another only considered hitting as violence if it was done in anger. The others thought that the context (e.g. selfdefence) was important in deciding if the act was or was not violent.

Of the ten respondents who cared for children, nine of them punished their children and six of them used violence to do so. Those who used violence on their children gave reasons which included:

- "when they have [done] something wrong or disobey my authority; when I punish them they know not to try and disobey me again or do something that is considered deviant behaviour"

- "I punish them because I want to stop them from doing wrong. If I punish them they will never do it again. For example: I got [caught] my teenage son smoking, man the slap I gave him, I know he won't try that no more."

- "If children are not corrected and disciplined how would they learn to respect themselves and other[s]? I occasionally spank them but not to injure them."

- "My mother used to knock me and my brothers out cold, she never used to play with us, am sure that was abuse, she used to hit us with anything close to her."

- "I got plenty 'cut hips' as a child, enough to last a life time.”

One male respondent added, "We live in The Bahamas man, which household with children don't tan up their behinds?”

\section{Perceptions of physical violence as abuse} Respondents considered that hitting became abuse when:

- "Someone [leaves] physical or emotional scar than may affect persons for life"

- "the pain is inflicted"

- "hitting someone so hard with an object which will leave a visible scar or mark" 
- "it becomes continuous and you're beaten to [an] unrecognizable state”

- "you leave marks on a person['s] body...A little hit is nothing to cry about but something that leaves a mark is very serious"

- "an individual's life is threatened or causes serious mental crisis... When an individual is beaten until he/she turns black and blue”

- "abuse to me is putting someone in the hospital. It's going to the extreme"

- "your parents over do it, in terms of hitting a child with a broom stick or trying to burn you with the iron."

One respondent who was not spanked as a child said that they spanked their children, but most parents who had been spanked as children said that they spanked their children. One respondent who had been abused by her mother (she was looked after by other relatives) refused to hit her child as she was "afraid that I would end up like my mother..." Only two of five respondents said that they would report abuse if they were aware that someone was being abused; these two respondents said that they themselves had been abused when they were children.

\section{Survey results Demographics}

Overall, a total of 1,037 people participated in the study, of whom 933 lived in homes with parents, their own home or a relation's home. Just over half (50.5\%) of all respondents lived in their parents' home, 37.1\% lived in their own home and $12.4 \%$ lived in another relative's home; the remainder lived in other types of home (e.g. dormitories). Not all forms were completed so the figure, 933, indicates the maximum sample size of the data retained for analysis.

Of the respondents retained in the analysis, $69.4 \%(n=927)$ were female and of 811 respondents 62.5\% were aged over 21 years. The most common marital status was single (44.0\%), 25.4\% were married, $24.5 \%$ in steady boyfriend or girlfriend relationships, while $2.4 \%$ were in common-law relationships and the remainder of the participants were in other relationships ( $n=909)$. There were children in 570 homes $(62.1 \%, n=918)$. Pets were reported by 466 respondents (50.6\%, $n=921$ ); pets and children were found in 322 homes (57.5\%, $n=906)$.

\section{The link between spanking of children and behaviours of concern}

The use of spanking to discipline children was reported by $77.1 \%$ of 555 respondents. Many respondents indicated that children were spanked only when very naughty (37.0\%), $27.5 \%$ sometimes, $25.8 \%$ rarely and $9.7 \%$ often $(n=422)$. All members of the household (parents, siblings and other relatives) spanked children. Respondents identified mothers as being primarily responsible for spanking children $(79.1 \%, n=426)$, then fathers $43.4 \%$, siblings $20.9 \%$, other relations $14.8 \%$ and finally non-relations $2.1 \%$. Of 418 respondents, $4.1 \%$ considered the spanking to be abuse. No one parent was more associated with abuse of children by spanking than the other, $2.1 \%$ of 331 mothers and 3.8\% of 183 fathers, $O R$ (fathers compared to mothers) $1.84,95 \%$ CI [0.64-5.33].

Domestic violence was found in $23.2 \%$ of 889 homes. The use of violence to train pets was reported in $24.9 \%$ of 405 homes with pets, and in $14.6 \%$ of 460 homes it was reported that pets were intentionally harmed. In 272 homes where there were pets and children, $11.4 \%$ contained all three types of violence and $12.1 \%$ had none of these sources of violence; in the wider population of all homes, at least one of the three types of violence studied, violence towards children, pets and domestic violence, occurred in $62 \%$ of homes (see Figure 1). 
Figure 1

The overlap of violence towards children, pets and family members (domestic violence), 273 respondents with pets and children.

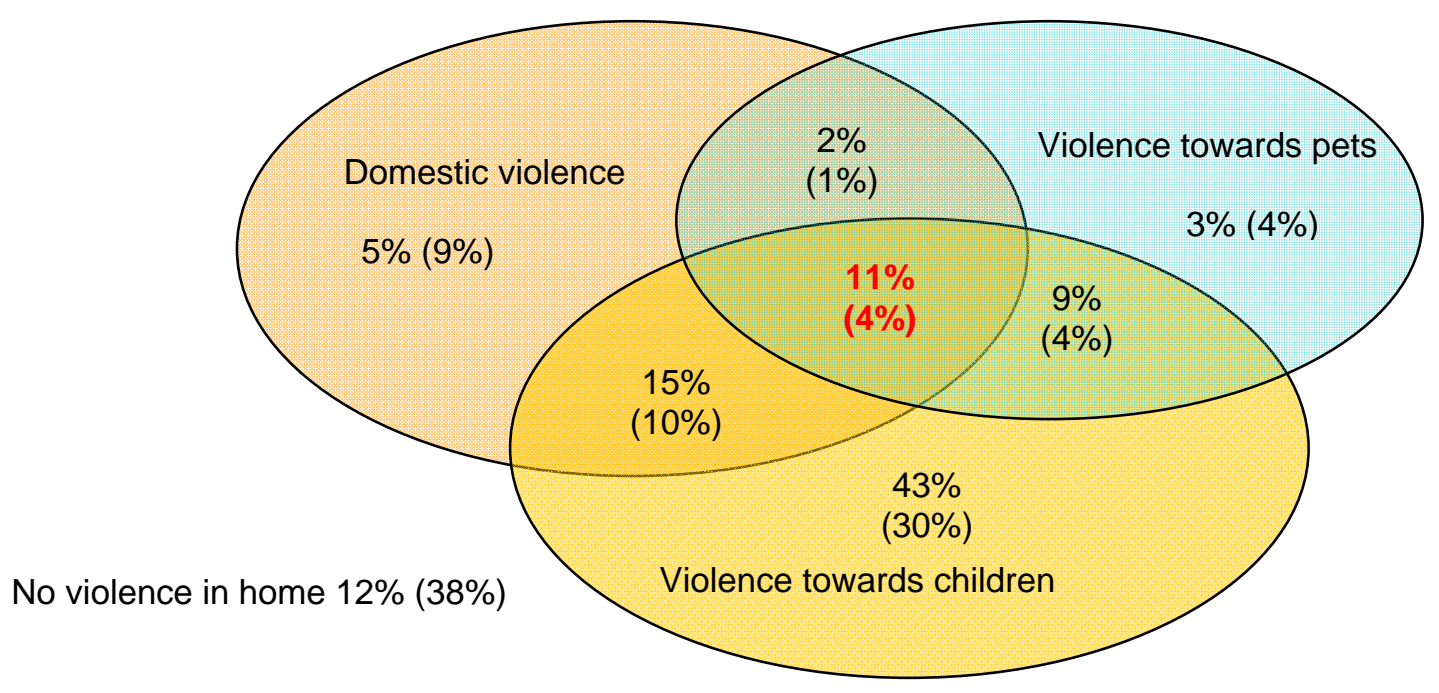

Note: Numbers in brackets refer to all households, 872 respondents

The use of spanking as a means of disciplining children was not found to be linked with the other behaviours of household members which we investigated (see Table 3). The spanking of children often was linked to domestic violence in the home and abuse (Table 3). However, spanking children often was not clearly identified as being abusive. The use of violence towards pets, or the care of pets was unrelated to the use of violence towards children, either as a means of discipline or the perception of abuse of the child or the spanking of children often.

When the spanking was considered to be abuse, it was found was to be linked to a number of behaviours, including domestic violence, alcohol abuse, use of illegal drugs, sexual abuse and the presence of a person within the home with a criminal record (Table 3). Further, when the spanking was considered abuse, the person responsible for the abuse was more likely to be the same person who also intentionally harmed the pets, than when the spanking was not abuse, so demonstrating the link between the behaviours, of harming people and pets, $O R$ (spanking is abuse compared to not abuse) 9.77, 95\% CI [2.71-35.2]. 
Table 3

The association between the spanking of children and spanking considered as abuse and activities/perceptions of household members as reported by on-and off-campus respondents.

\begin{tabular}{|c|c|c|c|c|c|c|c|c|c|}
\hline \multirow[b]{2}{*}{ Item } & \multicolumn{3}{|c|}{$\begin{array}{l}\text { Children spanked as means of } \\
\text { discipline }\end{array}$} & \multicolumn{3}{|c|}{ Children spanked often } & \multicolumn{3}{|c|}{$\begin{array}{l}\text { Spanking of the children } \\
\text { considered abuse }\end{array}$} \\
\hline & Yes & No & $\begin{array}{l}\text { Fisher's } \\
\text { exact test }\end{array}$ & Yes & No & $\begin{array}{l}\text { Fisher's } \\
\text { exact test }\end{array}$ & Yes & No & $\begin{array}{l}\text { Fisher's } \\
\text { exact test }\end{array}$ \\
\hline Pets well cared-for§ & $89.2 \%$ & $92.5 \%$ & $\begin{array}{l}p=0.20 \\
n=307 \\
d f=2\end{array}$ & $78.3 \%$ & $90.7 \%$ & $\begin{array}{l}p=0.083 \\
n=250 \\
d f=2\end{array}$ & $75.0 \%$ & $90.1 \%$ & $\begin{array}{l}p=0.22 \\
n=233 \\
d f=2\end{array}$ \\
\hline $\begin{array}{l}\text { Respondent lives in a } \\
\text { loving household }\end{array}$ & $88.4 \%$ & $87.2 \%$ & $\begin{array}{l}p=0.75 \\
n=547\end{array}$ & $75.0 \%$ & $90.2 \%$ & $\begin{array}{l}p=0.015 \\
n=437\end{array}$ & $41.2 \%$ & $90.9 \%$ & $\begin{array}{l}p \ll 0.001^{*} \\
n=412\end{array}$ \\
\hline $\begin{array}{l}\text { Domestic violence in the } \\
\text { household }\end{array}$ & $29.1 \%$ & $28.0 \%$ & $\begin{array}{l}p=0.91 \\
n=523\end{array}$ & $59.5 \%$ & $25.5 \%$ & $\begin{array}{l}p<0.001^{*} \\
n=418\end{array}$ & $68.8 \%$ & $26.6 \%$ & $\begin{array}{l}p<0.001^{*} \\
n=359\end{array}$ \\
\hline $\begin{array}{l}\text { Pets hit as means of } \\
\text { discipline }\end{array}$ & $25.8 \%$ & $22.4 \%$ & $\begin{array}{l}p=0.73 \\
n=275\end{array}$ & $28.6 \%$ & $24.9 \%$ & $\begin{array}{l}p=0.79 \\
n=226\end{array}$ & $54.5 \%$ & $23.5 \%$ & $\begin{array}{l}p=0.031 \\
n=211\end{array}$ \\
\hline $\begin{array}{l}\text { Respondents would } \\
\text { leave the household if } \\
\text { they could }\end{array}$ & $22.6 \%$ & $16.7 \%$ & $\begin{array}{l}p=0.21 \\
n=536\end{array}$ & $35.0 \%$ & $20.8 \%$ & $\begin{array}{l}p=0.046 \\
n=430\end{array}$ & $58.8 \%$ & $20.8 \%$ & $\begin{array}{l}p=0.001^{*} \\
n=406\end{array}$ \\
\hline Pets intentionally harmed & $18.0 \%$ & $11.6 \%$ & $\begin{array}{l}p=0.27 \\
n=306\end{array}$ & $34.8 \%$ & $15.6 \%$ & $\begin{array}{l}p=0.038 \\
n=247\end{array}$ & $25.0 \%$ & $17.4 \%$ & $\begin{array}{l}p=0.45 \\
n=230\end{array}$ \\
\hline $\begin{array}{l}\text { Alcohol used in excess } \\
\text { by a household member }\end{array}$ & $14.2 \%$ & $12.0 \%$ & $\begin{array}{l}p=0.66 \\
n=548\end{array}$ & $27.5 \%$ & $12.6 \%$ & $\begin{array}{l}p=0.015 \\
n=438\end{array}$ & $33.3 \%$ & $13.3 \%$ & $\begin{array}{l}p=0.045 \\
n=413\end{array}$ \\
\hline $\begin{array}{l}\text { The person who spanks } \\
\text { the child also hits the pet }\end{array}$ & $10.0 \%$ & $8.9 \%$ & $\begin{array}{l}p>0.99 \\
n=305\end{array}$ & $14.3 \%$ & $9.30 \%$ & $\begin{array}{l}p=0.50 \\
n=253\end{array}$ & $45.5 \%$ & $7.9 \%$ & $\begin{array}{l}p=0.002^{*} \\
n=240\end{array}$ \\
\hline Children spanked often & $9.7 \%$ & - & $n=422$ & - & - & - & $23.5 \%$ & $9.0 \%$ & $\begin{array}{l}p=0.069 \\
n=418\end{array}$ \\
\hline $\begin{array}{l}\text { Illegal drugs used by a } \\
\text { household member }\end{array}$ & $9.0 \%$ & $4.9 \%$ & $\begin{array}{l}p=0.19 \\
n=545\end{array}$ & $20.0 \%$ & $8.1 \%$ & $\begin{array}{l}p=0.021 \\
n=436\end{array}$ & $41.2 \%$ & $7.4 \%$ & $\begin{array}{l}p<0.001^{*} \\
n=411\end{array}$ \\
\hline $\begin{array}{l}\text { Household member with } \\
\text { criminal record§ }\end{array}$ & $6.3 \%$ & $4.8 \%$ & $\begin{array}{l}p=0.58, \\
n=552, \\
d f=2\end{array}$ & $14.6 \%$ & $5.2 \%$ & $\begin{array}{l}p=0.008 \\
n=442 \\
d f=2\end{array}$ & $17.6 \%$ & $6.0 \%$ & $\begin{array}{l}p<0.001^{*}, \\
n=417 \\
d f=2\end{array}$ \\
\hline $\begin{array}{l}\text { Any one sexually abused } \\
\text { in the household }\end{array}$ & $6.1 \%$ & $4.8 \%$ & $\begin{array}{l}p=0.67 \\
n=550\end{array}$ & $9.8 \%$ & $5.5 \%$ & $\begin{array}{l}p=0.29 \\
n=438\end{array}$ & $29.4 \%$ & $4.5 \%$ & $\begin{array}{l}p \ll 0.001^{*} \\
n=414\end{array}$ \\
\hline
\end{tabular}

Responses are limited to homes with pets and/or children as appropriate.

$\S$ Except for the item marked $\S$ when a Chi-squared test was used. Bonferroni adjustment, $p=0.0042$ for significance at the $5 \%$ level. Items significant at this level are indicated by an * 
The partial correlations in Table 4 show the underlying correlation between pairs of variables while allowing for the possible influence of all the other variables listed. When considering all the responses to look at the wider associations of behaviours in homes, it was seen that abusive spanking of children was correlated with other domestic violence, illegal drugs and spanking as a means of discipline (Table 4). The presence of spanking was not associated with the home being considered as loving, partial correlation $=0.01, p>0.05$, whereas when spanking was considered as abuse it was correlated, partial correlation $=$ $-0.15, p<0.001$.

Table 4

Partial correlations between the presence of household behaviours, all respondents. (Each correlation is conditional on other variables not in the pair.)

\begin{tabular}{|c|c|c|c|c|c|c|c|c|}
\hline & 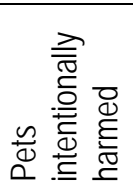 & 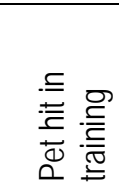 & 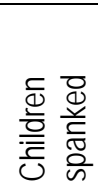 & 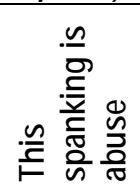 & 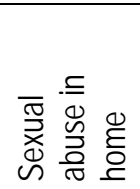 & 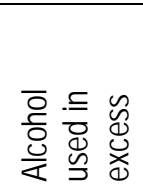 & 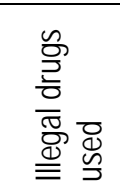 & 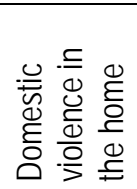 \\
\hline Pets intentionally harmed & - & $0.21^{\star \star \star}$ & $0.07^{\star}$ & -0.03 & 0.04 & $0.09 *$ & 0.02 & $0.14 * \star \star$ \\
\hline Pet hit in training & & - & 0.02 & 0.04 & 0.04 & 0.04 & 0.05 & $0.08 *$ \\
\hline Children spanked & & & - & $0.12^{\star \star *}$ & 0.00 & -0.01 & 0.01 & $0.08 *$ \\
\hline This spanking is abuse & & & & - & 0.01 & 0.01 & $0.09^{\star \star}$ & $0.10^{\star *}$ \\
\hline Sexual abuse in home & & & & & - & 0.05 & $0.14^{\star \star \star}$ & 0.06 \\
\hline Alcohol used in excess & & & & & & - & $0.29 * \star \star$ & $0.16^{\star \star \star}$ \\
\hline Illegal drugs used & & & & & & & - & $0.13^{\star \star \star}$ \\
\hline Domestic violence in the home & & & & & & & & - \\
\hline
\end{tabular}

Note: ${ }^{*}$ correlation significant $p<0.05,{ }^{* \star}$ correlation significant $p<0.01,{ }^{\star * *}$ correlation significant at $p<0.001$

\section{DISCUSSION}

The results illustrated the widespread occurrence of violence in respondents' homes as well as the co-occurrence of a number of undesirable activities including domestic violence, illegal drug use and sexual abuse. Violence towards animals was also common in homes with pets and was linked with violence towards children. These results repeated the linkages of undesirable household behaviours in college students' homes reported by Plumridge and Fielding (2009).

This study confirmed that the use of violence towards children in respondents' homes was common and even more likely in homes where there was domestic violence. In other words, it can be regarded as a part of the domestic violence landscape and it is understandable that such homes were not considered as loving by respondents. However, the use of violence towards children was so widespread that it was unrelated to the behaviours included in this study. However, hitting children often was not linked with several of the behaviours in the study. Hitting the child often was not clearly considered as abuse - the association was only significant at the $\mathrm{p}=0.069$. These findings are at variance with those found in other studies, such as in the study by DeGue and DiLillo (2009) who found that child abuse, domestic violence and animal abuse were interconnected. Again, this difference is probably due to fact that the perception of abuse in respondents' homes was different from that reported by others. The comparison of the definition offered by Sedlak (2001) and those offered by the case study participants indicates that what passes as abuse in The Bahamas is possibly at least "bodily harm” (Jones 2000). 
The association between spanking children, perceived as abuse, and misuse of alcohol by a household member was not statistically significant. This finding is inconsistent with the findings of other studies which have demonstrated the association between alcohol abuse and injuries to children (UNICEF, 2001). The lack of a linkage between spanking as abuse and use of alcohol probably reflected common use and misuse of alcohol within society which has been a cause for concern for many years (Spencer, 1972).

Illegal drug use is of concern particularly in a society such as The Bahamas which is located on a major drug trafficking route (U.S. Department of State, Bureau of International Narcotics and Law Enforcement Affairs, 2009). The linkage found in this study between illegal drug use and child abuse is a finding which has been noted by others (e.g., Prevent Child Abuse America, n.d.). This association further indicates the importance of education concerning drug use and law enforcement, as noted by others such as Smart and Patterson (1990), in order to protect children from harm.

This study has identified that three forms of violence, violence towards children, domestic violence and mistreatment of animals, were prevalent in respondents' households, the most common being violence towards children. This result is in line with that found in the study on school children in which many children claimed to have been abused (Bahamas Ministry of Health, Health Information Unit, 2001). The findings in this study suggest that the use of violence towards children was tolerated and even acceptable, as was the use of violence towards pets. While violence, when it becomes abuse may be less tolerated, respondents only considered extreme violence as abuse. The use of violence against children was not correlated with the home being considered a loving household and this suggests that this form of violence was not considered inconsistent with the household being a loving one. This attitude itself may be a cause for concern and results in underreporting of abuse cases as spanking can lead to abuse (Zolotor et al., 2008). The fact that respondents appeared to be unwilling to report abuse means that children can be at risk of severe harm yet remain beyond the reach of assistance.
It should be noted that unlike other reports (e.g., National Society for the Prevention of Cruelty to Children, n.d.) child abuse was not associated with the intentional harm of pets. This can be explained by the fact that the use of violence towards children and pets was so common that it did not stand out. Given that this phenomenon was common it is easy to assume that it is accepted as normal, even though pets are often considered as part of the household (Fielding, 2010). This explanation is in keeping with the statement from a case study participant: "Which household with children don't tan up their behinds?" The person who abused the child was likely to be the same person who hit the pet. This suggests that people who hit pets could be at higher risk of harming children and may need counselling.

The higher chance of a criminal being in a home where children were abused than when not abused may be a cause for concern as Greenfeld (1996) noted that in the United States "about 6 in 10 offenders who victimized children had previously served sentences to probation or incarceration, and 1 in 4 had a prior history of violence” (p. 3). Our finding suggests that there is a need for more research on this to determine if criminals in The Bahamas with a particular criminal history are more likely to abuse children and if so, what safeguards society should put in place to protect children.

The case studies indicated that violence had a broad interpretation. From the examples of violent acts it would appear that only acts involving considerable force (and so harm), even if insufficient to warrant medical attention, might actually be considered violent. This suggests that in the Bahamian context, acts which might be considered violent in other communities may not be thought of as being so. We note that respondents confused the act (hitting) with the context of the act (such as anger, self defence) which warrants further study. The case studies also showed that what is perceived as abuse can take the form of physical injuries which may require medical treatment. This suggested that violence was being regarded as abuse only when that violence resulted in severe harm to the victim. As such, this view focuses on the visible physical 
damage which violence can inflict rather than the subtler emotional damage associated with physical violence; as has been noted by others, "emotional and/or psychological abuse...is almost always present in families where physical and/or sexual domestic violence occur” (National Council on Child Abuse \& Family Violence, 2009). Again, this study linked a higher chance of sexual abuse and domestic violence occurring with households where spanking children was considered abuse. Further, the long-term damage that can be done to children was, presumably, not appreciated by those in this study who inflicted violence upon children (Shen, 2009). It would appear that the need to reduce corporal punishment is as great today as in 1996 when there was a call for community-based programmes to reduce corporal punishment in the Caribbean (Levav, Guerrero, Phebo, Coe, \& Cerqueira, 1996).

As many of the participants in the case studies admitted to being abused this also indicated that child abuse is common and not so rare as some people may perceive. The case studies provide further evidence to suggest that abuse of children is widespread both now and in previous generations and is consistent with the findings from the 1960s of Otterbein and Otterbein (1973). The case studies indicated that being a victim of violence sometimes made that person eschew violence when a parent. However, most such parents used violence to train their children and so perpetuated the use of violence in the next generation. Even when the respondent felt that their parents had abused them physically, the victim still felt that violence was the way to train children. Consequently, this supports the view that parental violence towards children is a learnt behaviour and so typical of other types of violence (Mouzos \& Makkai, 2005).

Only those case study participants who themselves had been abused said they would report cases of abuse. This indicates that the public must be educated to be aware that abuse should not be considered an activity which they can ignore. Unless neighbours assist social workers and police to identify abuse and violence then society becomes complicit in the harm which accrues to victims of abuse. Although the government website states that "all persons have a moral obligation" (Bahamas Department of Social Services, 2005a, para. 4) to report child abuse, study respondents seemed to disagree. This may be a part of a community trait which shows reluctance to involve the authorities in the behaviour of their neighbours (Adderley, 2008). If so, this suggests that a sustained educational campaign would be beneficial if the social services are to be able to safeguard those at risk of victimization.

As Pinder (2008) reported, while parents lament the violence in the schools they themselves may have already sown the seeds of violence which they see in schools. The potential for extreme violence amongst school children can be gauged by the fact that $5.7 \%$ of primary school students and $25.2 \%$ of junior/senior high school students take weapons to school (Bahamas Ministry of Education \& The College of The Bahamas, 2009). Further, this violence can be seen on the streets when students leave school and so the cycle of violence continues (Widom, 1989). We conjecture that the participants who hit children were unaware of the wider implications of their actions. If we are correct, this is an important topic for public education. It would appear that study respondents were only concerned with imposing a punishment on the child which, in their eyes, would have immediate results, while overlooking the longer-term implications of their actions. Further research would be needed to examine this. Although some may consider hitting children as part of Bahamian culture (as indicated by one respondent), the time may have come for the country to revisit this view and assess whether or not it actually contributes to the violence seen throughout society. Further, if it is agreed that freedom from violence is a basic human right, society may wish to decide to extend this freedom to children (Bartman, 2002).

\section{Limitations of the study}

Results from a convenience sample may be biased and so may not apply to the population beyond those sampled. No quota was imposed on the sample to get a balance between males and females of different ages and it is possible that different subgroups may have responded 
differently. It should be noted that while perceptions may be expected to be a function of the respondent, factual data should not be. This study focused on physical forms of violence only; other forms of violence also have an important role on the behaviour of people and so could be included in future studies.

\section{REFERENCES}

Adderley, C. R. (2008). Neighbourhood nuisances in The Bahamas: The case of New Providence. The College of The Bahamas Research Journal, 14, 4-12. Retrieved from http://researchjournal.cob.edu.bs

Aranha, K. (2009). Put a little love in your heart. The Bahamas Weekly. Retrieved from http://www.thebahamasweekly.com/publish/th e-pet-pages/Put_a_Little_Love_in_Your005939.shtml

Ascione, F. R. (Ed.). (2008). The international handbook on animal abuse and cruelty: Theory, research, and application. West Lafayette, IN: Purdue University Press.

Ascione, F. R., \& Arkow, P. (Eds.). (1999). Child abuse, domestic violence, and animal abuse: Linking the circles of compassion for prevention and intervention. West Lafayette, IN: Purdue University Press.

Bahamas Crisis Centre (n.d.). Physical abuse. Retrieved from http://www.bahamascrisiscentre.org/page11.html

Bahamas Department of Social Services. (2005a). What is child abuse? Retrieved from http://www.bahamas.gov.bs/bahamasweb2/ho me.nsf/vContentW/E79D072C0AD60A84852 56FA90054221C

Bahamas Department of Social Services. (2005b). Frequently asked questions: What is child abuse? Retrieved from http://www.bahamas.gov.bs/bahamasweb2/ho me.nsf/vContentW/b600c6c634287b3f852574 19006335ba!OpenDocument\&ExpandSection =1,6,2\#_Section1
Bahamas Department of Social Services. (2008). [Child abuse statistics, 1990-2007]. Unpublished raw data.

Bahamas Department of Social Services. (2009). [Child abuse statistics, 2008]. Unpublished raw data.

Bahamas Department of Statistics. (2002). Report of the 2000 census of population \& housing. Nassau, Bahamas: Ministry of Economic Development.

Bahamas Department of Statistics. (2008). [Household income by head of household classed by marital status in homes with children, from 2000 census]. Unpublished raw data.

Bahamas Ministry of Education, \& The College of The Bahamas (2009). [Survey of school children in The Bahamas]. Unpublished raw data.

Bahamas Ministry of Health, Health Information Unit. (2001). [Bahamas youth health survey]. Unpublished raw data.

Ballance, V. C. F. (2008). Bahamas (Commonwealth of). In: C. E. D’Avanzo (Ed.), (4th ed.). Pocket guide to cultural health assessment (pp. 48-52). St. Louis, MO: Mosby.

Bartman, A. (2002). Spare the rod and spoil the child: Corporal punishment in schools around the world. Indiana International \& Comparative Law Review, 13, 283-315.

Bhatt, R. V. (1998). Domestic violence and substance abuse. International Journal of Gynaecology \& Obstetrics, 63(Suppl. 1), S35S31. 
Brennen, S., \& Social Work 420 Students. (2008, May). Child welfare services and the family: Community resource manual. Unpublished manuscript, Department of Psychology, Sociology \& Social Work, College of The Bahamas, Nassau, Bahamas.

Burnett-Garraway, C. H. (2001). Domestic violence: A study of the occurrence and predictors in an accident and emergency department, The Bahamas. (Unpublished doctoral dissertation). University of the West Indies, School of Clinical Medicine and Research, Cave Hill, Barbados.

Children and Young Persons (Administration of Justice) Act, 1947, [CH. 97], (Bahamas).

Retrieved from http://laws.bahamas.gov.bs/statutes/statute_CH APTER_97.html\#Ch97s17

Covell, K., Grusec, J. E., \& King, G. (1995). The intergenerational transmission of maternal discipline and standards for behavior. Social Development, 4, 32-43. doi:10.1111/j.14679507.1995.tb00049.x

D’Avanzo, C. E. (Ed.). (2008). Pocket guide to cultural health assessment. (4th ed.). St. Louis. MO: Mosby.

DeGue, S., \& DiLillo, D. (2009). Is animal cruelty a "red flag" for family violence? Investigating co-occurring violence toward children, partners, and pets. Journal of Interpersonal Violence, 24(6), 1036-1056. doi:10.1177/0886260508319362

Fielding, W. J. (2010). Determinants of the level of care provided for various types and sizes of dogs in New Providence, The Bahamas.

International Journal of Bahamian Studies, 16, 63-76. Retrieved from

http://researchjournal.cob.edu.bs

Fielding, W. J., \& Plumridge, S. J. (2010). The association between pet care and deviant household behaviours in an Afro-Caribbean, college student community in New

Providence, The Bahamas Anthrozoös, 23, 69-
78. doi:

10.2752/175303710X12627079939224

Firmin, M. W., \& Castle, S. L. (2008). Early childhood discipline: A review of the literature. Journal of Research on Christian Education, 17, 107-129. doi:10.1080/10656210801909715

Fukurode, M. L. (2005). Murder at home: An examination of legal and community responses to intimate femicide in California. Los Angeles: California Women's Law Center. Retrieved from http://www.cwlc.org/files/docs/MurderAtHom e_FULL_REPORT.pdf

Greenfeld, L. A. (1996). Child victimizers: Violent offenders and their victims. (NCJ-153258). Washington, DC: Bureau of Justice Statistics. Retrieved from http://bjs.ojp.usdoj.gov/content/pub/pdf/CVVO ATV.PDF

Hackett, S., \& Uprichard, E. (2007). Animal abuse and child maltreatment: A review of the literature and findings from a UK study. London: National Society for the Prevention of Cruelty to Children. Retrieved from: http://www.nspcc.org.uk/Inform/publications/d ownloads/animalabuseandchildmaltreatmentful lreport_wdf51934.pdf

Halcon, L., Blum, R. W., Beuhring, T., Pate, E., Campbell-Forrester, S., \& Venem, A. (2003). Adolescent health in the Caribbean: A regional portrait. American Journal of Public Health, 93(11), 1851-1857. doi:10.2105/AJPH.93.11.1851

Is sparing the rod spoiling the child? (2008, August 21). The Nassau Guardian, pp. REL 1, REL 13. Retrieved from http://archive.nassauguardian.net

Jones, K. (2008, September 26). Child abuse in schools rising. The Bahama Journal. http://www.jonesbahamas.com/news/45/ARTI CLE/18403/2008-09-26.html.

Jones, S. (2000). Understanding violent crime. Buckingham, England: Open University Press. 
Retrieved from http://mcgrawhill.co.uk/openup/chapters/0335204171.pdf

Knowles, L. M. (1999). The impact of physical abuse on the psychological and behaviour state of institutionalised children in the Bahamas and Jamaica. (Unpublished doctoral dissertation) University of the West Indies, Mona, Jamaica.

Krug, E. G., Dahlberg, L. L., Mercy, J. A., Zwi, A. B., \& Lozano, R. (Eds.). (2002). World report on violence and health. Geneva: World Health Organization. Retrieved from http://libdoc.who.int/publications/2002/924154 5615_eng.pdf

Levav, I., Guerrero, R., Phebo, L., Coe, G., \& Cerqueira, M. T. (1996). Reducing corporal punishment of children: A call for a regional effort. Bulletin of the Pan American Health Organization, 30(1), 70-79.

Lightbourne, S. L. (2008, March 3). Domestic violence remains major concern. The Bahama Journal. Retrieved from http://www.jonesbahamas.com/?c=45\&a $=1608$ 7

Lockwood, R., \& Ascione, F.R. (1998). Cruelty to animals and interpersonal violence: Readings in research and application. West Lafayette, IN: Purdue University Press.

Maruyama, M., \& Ascione, F. R. (2008). Animal abuse: An evolving issue in Japanese society. In: F. R. Ascione (Ed.). The international handbook of animal abuse and cruelty: Theory, research, and application (pp. 269303). West Lafayette, IN: Purdue University Press.

Maycock, D. (2009, October 24). Teacher charged with indecently assaulting student. The Tribune. Retrieved from http://www.tribune242.com/searchresults/2410 09_teacher_news_pg1

McEwen, F. (2010, January 12). Animal abuse, child abuse, domestic violence: Research review. Community Care Inform. Retrieved from http://www.ccinform.co.uk/.

McKenzie, N. (2008, August 7). Baby sitter fined for spanking infant. The Tribune, p. A3.

McPhedran, S. (2009). Animal abuse, family violence, and child wellbeing: A review. Journal of Family Violence, 24, 41-52. doi:10.1007/s10896-008-9206-3

Mouzos, J., \& Makkai, T. (2004). Women's experiences of male violence: findings from the Australian component of the International Violence Against Women Survey. Canberra: Australian Institute of Criminology. Retrieved from http://www.aic.gov.au/documents/5/8/D/\%7B5 8D8592E-CEF7-4005-AB11B7A8B4842399\%7DRPP56.pdf

National Council on Child Abuse \& Family Violence. (2009). Spouse/partner abuse information. Retrieved from http://www.nccafv.org/spouse.htm

National Society for the Prevention of Cruelty to Children. (2005). Understanding the links: Child abuse, animal abuse and domestic violence: Information for professionals. (Rev. ed.). Retrieved from http://www.nspcc.org.uk/Inform/publications/ Downloads/understandingthelinks_wdf48177.p df (pamphlet)

Otterbein, C. S., \& Otterbein, K. F. (1973). Believers and beaters: A case study of supernatural beliefs and child rearing in the Bahama Islands. American Anthropologist, 75(5), 1670-1681. doi:10.1525/aа.1973.75.5.02a00290

Palmer, S., Lowe, C., Hepburn, D., Strachan, C., Symonette, K., \& Moss, V. (2008). Reaction paper. [A collection of media articles on the welfare of children in The Bahamas to 2008]. Unpublished manuscript.

Pinder, M. N. (2008, April 11). Parents in antiviolence pact. The Bahama Journal. Retrieved 
from

http://www.jonesbahamas.com/news/45/ARTI CLE/16636/2008-04-11.html

Plumridge, S. J., \& Fielding, W. J. (2009). Domestic violence in the homes of college students, New Providence, The Bahamas. The College of The Bahamas Research Journal, 15, 45-55. Retrieved from http://researchjournal.cob.edu.bs

Prevent Child Abuse America (n.d.). Fact sheet: The relationship between parental alcohol or other drug problems and child maltreatment. Retrieved from http://member.preventchildabuse.org/site/DocS erver/parental_alcohol.pdf?docID=125

Rivett, M., \& Kelly, S. (2006). From awareness to practice: Children, domestic violence and child welfare. Child Abuse Review, 15(4), 224-242. doi:10.1002/car.945

Sedlak, A. J. (2001). A history of the National Incidence Study of Child Abuse and Neglect. Washington, DC: U.S. Department of Health and Human Services, Children's Bureau. Retrieved from https://www.nis4.org/NIS_History.pdf

Shen, A. C. (2009). Long-term effects of interparental violence and child physical maltreatment experiences on PTSD and behavior problems: A national survey of Taiwanese college students. Child Abuse \& Neglect, 33(3), 148-160. doi:10.1016/j.chiabu.2008.07.006

Sherin, K. M., Sinacore, J. M., Li, X., Zitter, R. E., \& Shakil, A. (1998). HITS: A short domestic violence screening tool for use in a family practice setting. Family Medicine, 30(7), 508-512. Retrieved from http://www.stfm.org/fmhub/FULLPDF/JULY AUG98/cram1.pdf

Smart, R. G., \& Patterson, S. D. (1990). Comparison of alcohol, tobacco, and illicit drug use among students and delinquents in the Bahamas. Bulletin of the Pan American Health Organization, 24(1), 39-45.
Smith, D. E., \& Mosby, G. (2003). Jamaican child-rearing practices: The role of corporal punishment. Adolescence, 38(150), 369-381.

Spanking of children outlawed in Costa Rica. (2008, June 27). Retrieved from http://insidecostarica.com/dailynews/2008/june /27/nac04.htm

Spencer, D. J. (1972). Suicide in the Bahamas. International Journal of Social Psychiatry, 18(2), 110-113. doi: 10.1177/002076407201800205

Tertullien, M. C. (2002). Bahamian sayings: Bahamian culture \#2. Nassau, Bahamas: Media Publishing.

Thompson, K. L., \& Gullone, E. (2003). Promotion of empathy and prosocial behaviour in children through humane education. Australian Psychologist, 38(3), 175-182. doi:10.1080/00050060310001707187

Thompson, T. (2009, September 26). Mum slams school 'beating' of daughter. The Tribune. Retrieved from http://www.tribune242.com/searchresults/0926 2009_beating_news_pg1

Turnquest, R. G. (2009, November 11). Two stabbed in school fight. The Tribune. Retrieved from http://www.tribune242.com/searchresults/1111 2009_Stabbing_news_pg1

UNICEF. (2001). A league table of child deaths by injury in rich nations. Innocenti Report Card, 2. Retrieved from http://www.childpolicyintl.org/publications/A \%20league\%20table\%20of\%20child\%20death s\%20by\%20injury\%20in\%20rich\%20nations.p df

United Nations Office on Drugs and Crime, \& World Bank. (2007). Crime, violence, and development: Trends, costs, and policy options in the Caribbean. (Report No. 37820.) Washington, DC: Author. Retrieved from http://go.worldbank.org/HDBCAXW850 
U.S. Department of Health and Human Services, Children's Bureau. (2008). Long-term consequences of child abuse and neglect. Retrieved from Child Welfare Information Gateway http://www.childwelfare.gov/pubs/factsheets/l ong_term_consequences.cfm.

U.S. Department of State, Bureau of Democracy, Human Rights and Labor. (2009). 2008

Human rights reports: The Bahamas. Retrieved from http://www.state.gov/g/drl/rls/hrrpt/2008/wha/ 119146.htm

Widom, C. S. (1989, April 14). The cycle of violence. Science, 244(4901), 160-166. doi:10.1126/science.2704995

Wilson, J. K. (2005). When violence begins at home: A comprehensive guide to understanding and ending domestic abuse. (2nd ed.). Alameda, CA: Hunter House.

Zolotor, A. J., Theodore, A. D., Chang, J. J., Bekoff, M. C., \& Runyan, D. K. (2008). Speak softly-and forget the stick: Corporal punishment and child physical abuse. American Journal of Preventive Medicine, 35(4), 364-369. doi:10.1016/j.amepre.2008 